\title{
SECENTRALISATIE WET VAN NEDERLAND INDIES 1903
}

\author{
Teti Hestiliani \\ Program Studi Magister Pendidikan Sejarah, \\ Universitas Negeri Yogyakarta \\ Tetihestiliani.2018@student.uny.ac.id
}

\begin{abstract}
ABSTRAK
Pada akhir abad ke 19 terjadi perubahan terhadap sistem pemerintahan di Hindia Belanda, sebelumnya diterapkan sistem sentralis yang mana segala kegiatan diatur oleh pemerintahan pusat di Batavia. Kemudian hal ini menjadi semakin kompleks ketika berbagai urusan di daerah harus menjadi urusan pusat. Perubahan sistem pemerintahan di Hindia Belanda ini kemudian diperhatikan oleh berbagai tokoh di parlemen Belanda dan pejabat pemerintahan di Hindia Belanda. Perubahan sistem pemerintahan ini juga sebagai upaya untuk meningkatkan taraf hidup di Hindia Belanda yang dianggap bukan lagi sebagai daerah yang menguntungkan (wingewest). maka pada tahun 1901 melalui pidatonya Ratu Wilhelmina menyampaikan harus adanya perubahan terhadap sistem pemerintahan di Hindia Belanda. Kemudian pada tahun 1903 dikeluarkanlah Undangundang desentralisasi sebagai dasar otonomi daerah di Hindia belanda.
\end{abstract}

\section{Kata kunci : Desentralisasi, Hindia belanda, Kota}

\begin{abstract}
At the end of the 19th century there was a change in the system of government in the Dutch East Indies, before a central system was implemented in which all activities were regulated by the central government in Batavia. Then this becomes increasingly complex when various affairs in the region must become central business. The change in the system of government in the Indies was then noticed by various figures in the Dutch parliament and government officials in the Dutch East Indies. This change in the system of government was also an effort to improve the standard of living in the Indies which was considered no longer a wingewest area. then in 1901 through his speech Ratu Wilhelmina conveyed that there must be a change in the system of government in the Indies. Then in 1903 a decentralization law was issued as the basis for regional autonomy in the Dutch EastIndies.
\end{abstract}

\section{Keywords: Decentralization, Dutch East Indies, City}

\section{PENDAHULUAN}

Pada akhir abad ke-19 keadaan

daerah-daerah di Hindia Belanda mulai diperhatikan oleh pemerintah Belanda.

Hal ini dikarenakan timbulnya kesadaran moral setelah terjadinya eksploitasi terhadap rakyat pribumi melalui culturstelsel (sistem tanam paksa) pada masa pemerintahan Gubernur Jendral Johannes van den Bosch pada tahun 1830 di Hindia Belanda. Sistem tanam paksa yang diterapkan di Hindia Belanda Tidak dapat dipungkiri memberikan 
keuntungan yang sangat besar bagi negeri Belanda saat itu, menurut seorang Sosialis Demokrat Josef Emanuel Stokis bahwa Belanda memperoleh keuntungan sebesar 823 juta gulden sejak van den Bosch mengirimkan keuntungan pertama pada tahun 1831. Pada periode ini Hindia Belanda hanya dianggap sebagai daerah eksploitasi tanpa dipenuhi hak-hak nya sebagai daerah koloni. (Gouda, 2007:53).

Pada bidang pemerintahan Hindia Belanda diatur dibawah negeri Belanda langsung dan berbagai kebijakan yang berlaku bergantung pada kondisi politik negara Belanda saat itu. Anggapan sebelumnya dengan semboyan Verloren Rampsoed Geboren (hilangnya Indonesia berarti lahirnya mala petaka) menganggap bahwa Hindia Belanda hanya sebagai komoditas menguntungkan bagi Belanda dan tidak memperhatikan kehidupan rakyat pribumi. Munculnya ketakutan lepasnya wilayah Hindia Belanda ini menimbulkan anggapan bahwa harus diterapkan sistem pemerintahan baru bagi Hindia Belanda, maka sistem pemerintahan yang dianggap paling tepat yaitu sistem pemerintahan sentralis atau sistem pemerintahan terpusat. Segala sesuatu berasal dan diatur dari pusat, serta diselenggarakan oleh pemerintah pusat dan tidak terbuka nya kemungkinan untuk dilaksanakan otonomi daerah pada pertengahan abad ke 19.

Sistem pemerintahan di Hindia Belanda diatur berdasarkan undangundang dari negeri Belanda. undangundang ini diberi nama Reglemen Pemerintah Tentang Kebijaksanaan Pemerintah Hindia Belanda (Reglement Op het Beleid der Regering Van Nederlands Indie atau disingkat Regeringsreglement atau lebih di singkat lagi R.R. ) pada tanggal $1 \mathrm{Mei}$ 1855, berdasarkan pasal 71 R.R pemerintah di Hindia Belanda di jalankan secara sentralis. Dengan kata lain pemerintahan hanya dijalankan satu arah segala sesuatu diatur oleh pusat dan diselenggarakan oleh pemerintah pusat. Meskipun suatu permasalahan lokal yang bersifat sederhana dan tidak berarti masih menjadi urusan pusat. Hal ini membuat banyak daerah-daerah di Hindia Belanda tidak mendapat perhatian yang baik dari pemerintah pusat di Batavia ( Surianingrat, 1981:11).

Keadaan daerah-daerah Hindia Belanda yang memprihatinkan 
menimbulkan beberapa simpati dari tokoh-tokoh di Belanda. Tokoh ini mulai menyuarakan hak hidup layak bagi rakyat pribumi di Hindia Belanda. Pada tahun 1858 seorang penulis anonim dengan inisial N.A. menulis sebuah artikel pendek berjudul "Varia" dalam Tijdschrift voor NederlandschIndie 20, No. 1 Tahun 1858 yang berisi kritikan mengenai kondisi Batavia yang tidak nyaman. Sebelumnya orangorang Belanda dan Eropa yang datang ke Hindia Belanda merasa nyaman untuk datang dan tinggal. Mereka menyebut Hindia Belanda sebagai Hindia yang cantik, yang nyaman sebagai tempat tinggal atau mooi indie. Mooi indie adalah sebuah gambaran yang menggambarkan kehidupan masyarakat Hindia Belanda yang damai, tenang dan harmonis.

Kemudian orang-orang Eropa dan Belanda yang datang ke Hindia Belanda mulai merasa bahwa sebenarnya Hindia Belanda tidak seteratur dan sebersih tempat asal mereka. Mereka beranggapan bahwa hal ini diakibatkan karena tidak adanya sebuah lembaga otonom yang mengelola daerah-daerah tersebut. Daerah-daerah ini tidak diberi kewenangan untuk mengelola daerahnya sendiri. Semua diatur oleh Gubernur Jendral yang berkedudukan di Batavia, sehingga kekuasaan seorang Gubernur Jendral sangat luas di Hindia Belanda. Kewenangan untuk memberikan otonomi pada daerahdaerah di tingkat lokal tidak dapat dibendung lagi.

Berdasarkan latar belakang di atas, dapat dilihat bahwa kondisi daerah-daerah di Hindia Belanda pada akhir abad ke 19 sangat memprihatinkan. Banyak daerah-daerah yang tidak mendapatkan perhatian yang layak dari pemerintah Belanda yang dalam hal ini melalui pemerintah pusat di Batavia. Hal ini dikarenakan semakin kompleksnya urusan pemerintah sehingga banyak daerah di Hindia Belanda tidak mendapatkan perhatian yang cukup. Oleh karena itu artikel ini juga berusaha menjawab permasalah berikut : (1) apa yang melatarbelakangi diberlakukannya Undang-Undang Desentralisasi di Hindia Belanda ? (2) bagaimana implementasi UndangUndang Desentralisasi di Hindia Belanda ? (3) bagaimana dampak diberlakukannya Undang-Undang Desentralisasi terhadap kondisi kotakota di Hindia Belanda? 


\section{METODE PENELITIAN}

Studi ini menggunakan sejumlah arsip kolonial yang merupakan sumber primer dan berbagai sumber lainnya sebagai sumber sekunder. Sumbersumber yang digunakan merupakan sumber yang relevan dan mengandung fakta sejarah. Adapun yang merupakan sumber primer diantaranya : Decentralisatie-wet ( Staatblad 1903 No 329), Decentralisatie Besluit ( Staatblad 1905 No. 137), Local raden-ordonnatie ( Staatblad 1905 No. 181). Selain itu juga terdapat sumber-sumber buku. Sumber-sumber yang digunakan diperoleh dari beberapa tempat, yaitu dari Arsip Nasional Republik Indonesia (ANRI) dan Perpustakaan Nasional Republik Indonesia (PNRI) dan berbagai perpustakaan lainnya diberbagai perpustakaan di Indonesia. Data-data yang diperoleh kemudian dianalisis melalui Metode Sejarah kemudian dihistoriografikan.

\section{HASIL DAN PEMBAHASAN}

\section{Kondisi Hindia Belanda Akhir abad 19}

Keadaan Hindia Belanda pada akhir abad 19 mulai ramai didatangi oleh orang-orang Eropa. Jumlah orangorang Eropa yang datang ke Hindia Belanda terus bertambah banyak termasuk dari negeri Belanda sendiri hal ini dikarenakan dibukanya Terusan Suez pada tahun 1869 yang memudahkan dan menyingkat waktu perjalanan dari Eropa ke Hindia Belanda tanpa harus mengelilingi Tanjung Harapan. Hubungan antara Hindia Belanda dan Belanda semakin meningkat setelah adanya perhubungan melalui telegraf pada tahun 1856 dan pos tahun 1862( Notosusanto dan Basri. 1980: 188). Perjalanan menuju Hindia Belanda juga menjadi lebih mudah setelah berkembangnya kapal-kapal pesiar pada tahun 1890, kapal-kapal pesiar ini milik K.P.M (koninklijk Paketvaart Maatchappij - Perusahaan Pelayaran Kerajaan Belanda). Lebih mudahnya perjalanan ke Hindia Belanda dibandingkan periode sebelumnya membuat orang-orang Eropa dan Belanda yang datang ke Hindia Belanda semakin bertambah. Hal ini membuat jumlah penduduk semakin bertambah pula. Penambahan jumlah penduduk ini tidak hanya di Batavia tetapi juga di kota-kota utama di Hindia Belanda (Rahman, 2016:115).

Pertumbuhan populasi penduduk yang signifikan di Hindia Belanda pada akhir abad ke 19 ini dikarenakan banyaknya orang-orang Belanda dan 
Eropa yang datang untuk bekerja di perkebunan yang banyak dibuka akibat dari pelaksanaan sistem ekonomi liberal pada tahun 1870 yang diterapkan di Hinida Belanda. Berbagai urusan yang bersifat lokal menjadi semakin kompleks sehingga menyulitkan pemerintah pusat.

\section{Proses Perumusan Decentralisatie Wet}

Persoalan perubahan bentuk pemerintahan di Hindia Belanda juga disuarakan di parlemen Belanda. Pada tahun 1880, L.W.C Keuchenius kembali memunculkan perdebatan mengenai perlunya dilakukan perubahan pada daerah-daerah jajahan, perubahan ini berhubungan pada struktur ketatanegaraan di Hindia Belanda agar tidak lagi bergantung pada Gubernur Jendral. Usulan mengenai desentralisasi bagi daerah-daerah di tanah jajahan ini juga disuarakan oleh para anggota parlemen lain seperti W.K Baron van Dadem pada tahun 1881, J.Th Cramer dan S. Van Houten pada tahun 1887. Kemudian pada periode selanjutnya upaya menyuarakan desentralisasi di daerah jajahan meningkat pada babak baru karena tokoh-tokoh yang mendukung desentralisasi menduduki posisi strategis pada pemerintahan Belanda. Tetapi usaha-usaha untuk mewujudkan desentralisasi belum bisa teralisasi meskipun keuchenius, van Dadem, J.Th. Cramer menduduki posisi sebagai menteri koloni. Di Hindia Belanda perubahan struktur pemerintahan juga disuarakan oleh van Der Wijck yang saat itu menjabat sebagai Gubernur Jendral. Rancangan undang-undang yang telah dirancang oleh J.Th. Cramer kembali digunakan oleh menteri koloni selanjutnya pada tahun 1901 (wignjosoebroto, 2014: 112114).

Perubahan sistem pemerintahan di Hindia Belanda menjadi daerah otonomi juga berasal dari Hindia Belanda itu sendiri dikarenakan semakin kompleksnya urusan yang bersifat lokal dan sederhana yang tidak dapat ditangani lagi oleh pemerintah pusat di Batavia. Maka, sangat diperlukan perubahan pada struktur pemerintahan saat itu. meningkatnya kegiatan yang bersifat lokal pada akhir abad ke 19 dikarenkan adanya perubahan sistem perekonomian di Hindia Belanda yang sebelumnya diatur oleh pemerintah kemudian pada masa sistem liberal diberikan kesempatan pihak swasta untuk menanamkan modal di Hindia Belanda mengakibatkan banyak perusahaan 
swasta yang dibuka. Akibatnya juga dibuka kantor-kantor dagang dan bankbank yang didirikan di beberapa kota besar di Hindia Belanda pada akhir abad ke 19. Semakin kompleksnya urusan yang bersifat lokal mendesak diadakannya desentralisasi bagi daerahdaerah di Hindia Belanda agar lebih mempermudah urusan dalam berbagai bidang (Handinoto, 2010:210).

Kemudian menanggapi segala hal yang mendesak diadakannya desentralisasi dari Belanda dan dari Hindia Belanda di buatlah sebuah rancangan undang-undang desentralisasi. Sebelumnya rancangan undang-undang desentralisasi yang diajukan oleh menteri koloni selalu saja menimbulkan perdebatan di negeri Belanda. Kemudian pada tahun 1901 Ratu Wilhelmina merencanakan pelaksanaan politik Etis di negeri jajahan. Konsep dari politik Etis ini yaitu etika Kristen dan kewajiban Belanda terhadap rakyat Hindia Belanda. Kemudian Hindia Belanda bukan lagi sebagai daerah wingewest (daerah yang menguntungkan), tetapi menjadi daerah yang perlu dikembangkan sehingga dapat dipenuhi keperluannya dan ditingkatkan taraf hidupnya. Beberapa bagian dari pemerintahan diperbaiki untuk menunjang pelaksanaan politik Etis. Salah satu bagian perbaikan organisasi pemerintahan tersebut adalah diberlakukannya undang-undang desentralisasi untuk memberikan dasar hukum desentralisasi bagi penguasa di tingkat lokal (Tanpa Nama, 2010: 212). Selanjutnya dua perubahan administratif diperkenalkan. Pertama, pada tahun 1901 pemerintah Hindia-Belanda mengizinkan politik etis sebagai undang-undang baru di koloni yang memungkinkan perencanaan, administrasi dan keruangan kota-kota koloni secara lokal. Kedua, dibukanya kemungkinan daerah-daerah di Hindia Belanda diberi otoritas sebagai Gemeente.

Pada tahun 1903 atas usul A.W.F Idenburg seorang menteri koloni pada Parlemen Belanda berhasil mengajukan undang-undang desentralisasi bagi daerah Hindia Belanda. Undang-undang yang diajukan oleh Indenburg ini tidak jauh berbeda dengan undang-undang yang diajukan sebelumnya, tetapi tidak mengalami perdebatan di Belanda dan usulannya di terima. Untuk diadakannya perubahan terhadap pasal 68 Regeringsreglement 1854 ( Undang-Undang Dasar bagi 
daerah jajahan Belanda) dengan penambahan pasal 68a, 68b, dan 68c, yang memberikan kesempatan untuk membentuk daerah-daerah otonom. Ketiga pasal tersebut meliputi(terjemahan) :

\section{Pasal 1}

Didalam reglement tentang pokok-pokok kebijaksanaan Pemerintah Hindia Belanda yang ditetapkan dengan Undang-undang tanggal 2 September 1854 (staatsblad No. 129), setelah pasal 68 disisipkan tiga pasal

\section{Pasal 68a \\ Jika} keadaan memungkinkan,untuk wilayah atau bagian-bagian dari wilayah akan diberikan uang dari daerah yang bersangkutan untuk membiayai kebutuhan-kebutuhan khusus daerah itu. Penunjukan wilayah atau bagian dari wilayah, dimana ketentuan diatas akan diterapkan, sejumlah uang dipisahkan dan kebutuhan yang bersangkutan tidak akan dibiayai lagi dari keuangan umum Hindia Belanda, diselenggarakan dengan ordonansi

\section{Pasal 68b}

Penggusuran dan pertanggung jawaban dari keuangan sendiri dari wilayah atau bagian wilayah diatur dengan peraturan umum dan pengawasan atas tanggung jawab dari bendaharawan tidak diatur dengan cara lain. Pengurusan pengeluaran tersebut sedapat mungkin diserahkan kepada dewan yang akan dibentuk dengan ordonasi untuk tiap wilayah, dimana ditetapkan ketentuan dari ayat satu pasal 68a.

Atas beban satu wilayah atau bagian dari wilayah tidak dapat diadakan pinjaman uang atau dijaminkan kecuali dengan syarat penguatan dari keputusan tersebut dengan ordonansi

\section{Pasal 68c}

Dewan-dewan yang dimaksud dalam ayat dua dari pasal $68 \mathrm{~b}$, berwenang untuk memperjuangkan kepentingan daerah, untuk mana dibentuk, kepada Gubernur Jendral.

Pasal-pasal tersebut diatas ditambahkan untuk memberikan kejelasan bahwa dengan dibentuknya daerah-daerah yang mengelola keuangan secara mandiri terpisah dari pemerintah pusat di Batavia. Untuk mengelola keuangan di tingkat lokal maka diperlukan untuk membentuk dewan lokal sehingga mampu mengelola keuangan secara mandiri pula. Usulan tersebut disusul dengan terbitnya Wethoudende Decentralisatie van het Bestuur in Nederlandsch-Indie pada tanggal 23 Juli 1903, atau lebih dikenal dengan nama Decentralisatie Wet 1903. Undang-undang ini kemudian dipublikasikan melalui Nederlandsche Staatblad tahun 1903 No. 219 dan melalui Indische Staatsblad No.329). Undang-undang tersebut merupakan undang-undang otonomi pemerintah pertama yang dikeluarkan di Hindia Belanda.

Implementasi Decentralisatie Wet di Hindia Belanda 
Dalam rangka pelaksanaan Decentralisatie Wet 1903 pemerintah Belanda mengeluarkan Decentralisatie Besluit 1905 dan Local Raden Ordonnantie, dalam Decentralisatie Besluit mengemukakan tentang pokokpokok pembentukan, susunan, kedudukan, dan wewenang dewan (Raad) dalam pengelolaan keuangan yang dipisahkan dari pemerintah pusat. Sedangkan Local Raden Ordonnantie merupakan aturan pelaksanaan yang menentukan struktur, status, kewenangan dewan (Raad), yaitu Gewestelijke Raad, Plaatselijk Raad, dan Gemeenteraad.

Dengan dasar undang-undang dan aturan tersebut maka daerah-daerah di Hindia Belanda yang telah memenuhi syarat diubah statusnya menjadi kota otonom yang memiliki pemerintahan sendiri yang terpisah dengan pemerintahan pusat tetapi tetap bertanggung jawab kepada pemerintah pusat (Gubernur Jendral). Pada hakekatnya Gemeente dan Kabupaten adalah kesatuan masyarakat hukum yang tingkatannya sama, pendapatan daerah serta hak dan kewajiban yang sama. Hanya saja Gemeente harus dipimpin oleh seorang walikota (burgermeester) oleh orang Belanda bukan pribumi. Anggota dewan kota (Gemeente raad) terdiri dari orang Belanda asli, Pribumi dan orang asing lainnya yang jumlahnya telah diatur oleh pemerintah Belanda. Undangundang Desentralisasi menciptakan dewan-dewan lokal, baik Dewan Keresidenan maupun Dewan Kota sebagai lembaga hukum yang mempunyai wewenang membuat peraturan. Desentralisasi ini mencakup tiga hal, yaitu :

1) Pendelegasian kekuasaan dari pemerintah pusat di Belanda ke Hindia-Belanda, kemudian dari pemerintahan ini ke departemen, pejabat lokal, dan dari pejabat Belanda ke pejabat pribumi,

2) Menciptakan lembaga-lembaga otonom yang mengatur urusan sendiri, dan

3) Memisahkan keuangan negara dan keuangan pribadi (Utomo, 2012:244).

Dengan dibentuknya Gemeente yang memiliki otoritas untuk mengelola kota, lembaga kemudian memperoleh hak yang melekat pada wewenang yang dimiliki. salah satu hak yang diberikan kepada Gemeente adalah hak untuk mengumpulkan pajak dari warga kota yang bersangkutan. Gemeente juga 
diberi hak untuk mengumpulkan dana dari usaha-usaha yang dialihkan oleh pemerintah pusat, penjualan dan penyewaan rumah, tanah dan lain-lain (Basundoro, 2012:93).

\section{KESIMPULAN}

Keadaan daerah-daerah di Hindia Belanda secara administratif diatur oleh pemerintah Belanda melalui Gubernur Jendral di Batavia. Pada pertangahan abad ke 19 Hindia Belanda dijalankan dengan pemerintahan sentralis. Kemudian sistem tersebut tidak lagi mampu menampung segala aktivitas di daerah yang semakin kompleks. Perdebatan mengenai bentuk pemerintahan di Hindia Belanda ini terus menjadi perdebatan di parlemen Belanda. Kekuasaan Gubernur Jendral yang sangat luas perlu dibatasi dengan adanya sebuah undang-undang yang mengatur sistem pemerintahan di daerah. Kemudian pada tahun 1901 dalam pidato nya Ratu Wilhelmina menyampaikan peraturan baru mengenai administrasi di daerah Hindia Belanda, maka pada tahun 1903 dikeluarkan Undang-Undang

Desentralisasi pertama di Hindia Belanda.

\begin{tabular}{|c|c|c|}
\hline \multicolumn{3}{|c|}{$\begin{array}{c}\text { DAFTAR KOTA-KOTA YANG DITETAPKAN } \\
\text { MENJADI GEMEENTE }\end{array}$} \\
\hline NAMA & $\begin{array}{l}\text { LUAS } \\
\text { KOTA }\end{array}$ & GEMEENTE \\
\hline Batavia & 155,4 & 1905 \\
\hline $\begin{array}{c}\text { Meester } \\
\text { cornelis } \\
\text { (Jatinegara) }\end{array}$ & 28,7 & 1905 \\
\hline Bogor & 21,69 & 1905 \\
\hline Cirebon & 10,4 & 1906 \\
\hline Bandung & 28,6 & 1906 \\
\hline Semarang & 99,4 & 1906 \\
\hline Tegal & 11,6 & 1906 \\
\hline Pekalongan & 12,2 & 1906 \\
\hline Magelang & 18,12 & 1906 \\
\hline Surabaya & 82,8 & 1906 \\
\hline Blitar & 6,4 & 1906 \\
\hline Kediri & 21 & 1906 \\
\hline Padang & 11,5 & 1906 \\
\hline Palembang & 21,75 & 1906 \\
\hline Makassar & 15,1 & 1906 \\
\hline Medan & 15,8 & 1909 \\
\hline sukabumi & 10,6 & 1914 \\
\hline Malang & 18,8 & 1914 \\
\hline Salatiga & - & 1917 \\
\hline Binjai & 3 & 1917 \\
\hline Tebing Tinggi & 3,8 & 1917 \\
\hline Tanjung Balai & 1,1 & 1917 \\
\hline $\begin{array}{l}\text { Pematang } \\
\text { Siantar }\end{array}$ & 8,5 & 1917 \\
\hline Mojokerto & 5,3 & 1918 \\
\hline Pasuruan & 13,75 & 1918 \\
\hline Probolinggo & 12,6 & 1918 \\
\hline Madiun & 9,7 & 1918 \\
\hline Bukit tinggi & 5,2 & 1918 \\
\hline Sawah Lunto & 5,9 & 1918 \\
\hline Banjarmasin & - & 1919 \\
\hline Manado & - & 1919 \\
\hline Ambon & - & 1921 \\
\hline
\end{tabular}




\section{REFERENSI}

\section{Arsip}

Decentralisatie-wet ( Staatblad 1903 No 329)

Decentralisatie Besluit ( Staatblad 1905 No. 137)

Local raden-ordonnatie ( Staatblad 1905 No. 181)

\section{Buku}

Basundoro, Purnawan. Pengantar Sejarah Kota. Yogyakarta: Penerbit Ombak,

Djenen, Dkk. 1972. Sumatera Selatan Dipandang Dari Sudut Geografi Sejarah Dan Kebudayaan. Proyek Inventarisasi Dan Dokumentasi Kebudayaan Nasional Direktorat Jendral Kebudayaan.

Gouda, Frances. 2007. Dutch Culture Overseas Praktik kolonial di Hindia Belanda, 1900-1942. Jakarta : PT Serambi Ilmu Semesta.

Handinoto, 2010. Arsitektur Dan KotaKota Di Jawa Pada Masa Kolonial. Yogyakarta: Graha Ilmu.

Notosusanto, Nugroho dan Basri, Yusmar. 1980. Sejarah Nasional Indonesia. Jakarta: Departemen Pendidikan dan Kebudayaan.

Rahman, Fadly. 2016. Rijsttafel Budaya Kuliner Di Indonesia Masa Kolonial 1870-1942. Jakarta: PT Gramedia Pusstaka Utama.

Surianingrat, Bayu. 1981. Sejarah Pemerintahan di Indonesia Babak
Hindia Belanda dan Jepang. Jakarta. Dewaruri Press.

Tanpa Nama, 2010. Indonesia dalam Arus Sejarah Masa Pergerakan Kebangsaan. Jakarta: PT. Ichtiar Baru van Hoeve.

Tim. 1998. Otonomi Daerah di Hindia Belanda 1903-1940. Jakarta. Arsip Nasional Republik Indonesia

Wallace, Alfred Russel. 2009. Kepulauan Nusantara : Sebuah Kisah Perjalanan, Kajian Manusia dan Alam. Depok: Komunitas Bambu

Wignjosoebroto, Soetandyo. 2004. Desentralisasi dalam Tata Pemerinthan Kolonial HindiaBelanda Kebijakan dan Upaya Sepanjang Babak Akhir Kekuasan Kolonial di Indonesia (19001940). Malang: Bayumedia Publishing.

Wignjosoebroto, Soetandyo. 2014. Dari Hukum Kolonial ke Hukum Nasional. Jakarta: HUMA 